\title{
Armenien:
}

\section{Valg og undtagelsestilstand}

\section{Søren Theisen}

\section{Den 54-årige Serzh Sargsyan vandt ikke uventet valget, men vejen fra stemmeurne til præsident- palads viste sig umiddelbart at blive mere kontro- versiel end først antaget}

Den 19. februar i år afviklede Republikken Armenien sit femte præsidentvalg efter selvstændigheden fra Sovjet i 1991. I alt ni kandidater opstillede til valget, men sejren tilfaldt ikke overraskende den 54-årige Serzh Sargsyan, der nu står til at blive landets tredje folkevalgte præsident siden uafhængigheden.

Vejen fra stemmeurne til præsidentpalads viste sig dog umiddelbart at blive mere kontroversiel end man først kunne antage. Undertegnede befandt sig i Armenien under valget som langtidsobservatør for OSCE/ ODIHR og blev derfor øjenvidne til begivenhederne.

Den 20. februar offentliggjorde den Centrale Valgkommission (CEC) således et foreløbigt valgresultat, der antydede at kandidat Sargsyan havde opnået 52,86 procent af de afgivne stemmer i forhold til sine to nærmeste rivaler, Levon Ter-Petrosyan, Armeniens første president fra 1991-98, med 21,50 procent af de afgivne stemmer og Arthur Baghdasaryan, leder af partiet Orinats Yergir (For en Retsstat), med 16,67 procent af de afgivne stemmer.

Begge disse havde desuden ført deres valgkamp som oppositionskandidater til det regeringsbærende Hayastan Hanrapetakan Khusakhtsutioun (Armeniens Republikanske Parti), som havde opstillet Serzh Sargsyan. Hvad angår de nævnte stemmetal, adskilte ingen af dem sig dog væsentligt fra det endelige valgresultat, der blev offentliggjort af CEC den 24. februar.

Den 20. februar offentliggjorde også OSCE/ODIHR's valgobservationsmission (EOM) sammen med OSCE's Parlamentariske Forsam- 
ling, Europaparlamentet og Europarådet en fælleserklæring, hvori det hed sig, at valget var blevet administreret overvejende i overensstemmelse med disse organisationers standarder, men samtidig gjorde opmærksom på en række problemer omkring valgprocessen, som de armenske myndigheder opfordredes til at søge rettet fremover.

Denne erklæring, der som sædvanligt var udarbejdet af hensyn til de tre diplomatiske delegationers hastværk, blev dog derfor også udsendt, inden samtlige detaljer fra valgnatten var kendt, og ligeledes før resultatet af omtællingerne af 135 valgsteder, som sideløbende gik i gang overvåget af de udstationerede langtidsobservatører, indløb.

Det medførte at OSCE/ODIHR så sig nødsaget til at udsende en såkaldt foreløbig post-elektoral rapport igen den 3 . marts med en betydeligt mere detaljeret og kritisk ordlyd.

\section{Kritik fra kandidaterne}

Allerede om formiddagen den 20. februar havde kandidat Levon TerPetrosyan imidlertid fremsat en række meget skarpe udtalelser i medierne, hvori han hævdede at hele valgprocessen havde båret præg af 'omfattende forfalskninger og overgreb', og at han selv som følge deraf havde vundet valget.

I samme åndedrag gav han OSCE /ODIHR skylden for diverse fore- komne uregelmæssigheder grundet organisationens 'dårlige observatører'. Desuden opfordrede han sine tilhængere til at samles i Jerevan til et 'sejrs- alternativt protestmøde'.

Også kandidat Arthur Baghdasaryan udtalte, at valgets gyldighed burde drages i tvivl som følge af mange uregelmæssigheder, selv om han pure afviste Levon Ter-Petrosyans påstand om sejr. Endelig valgte den fjerdebedst placerede kandidat, Vahan Hovhannisyan fra partiet Dashnaktsutioun (Armeniens Revolutionære Føderation), i protest at træde tilbage fra sin post som viceformand for parlamentet, selv om hans parti senere erklærede, at det ikke ville gøre formel indsigelse mod valgresultatet.

Blandt de øvrige kandidater hævdede Vazgen Manoukyan, at overgreb var forekommet, mens Tigran Karapetyan som den første rejste en formel anklage ved Forfatningsdomstolen den 27. februar, efterfulgt af Levon Ter-Petrosyan den 29. februar.

På hele denne baggrund indledte sidstnævntes tilhængere fra den 21. februar og de følgende 11 dage en fredelig 'sit in' demonstration på Frihedspladsen (tidl. Operapladsen) i Jerevan, afvekslende med protestmarcher ad byens hovedstrøg.

Skønt ingen af disse tiltag havde indhentet formel tilladelse, forholdt myndighederne sig generelt passivt indtil CEC's offentliggørelse af det 
endelige valgresultat den 24. februar, som gav tilhængere af Serzh Sargsyan og det Republikanske Parti anledning til selv at afholde moddemonstrationer både i hovedstaden og flere større provinsbyer.

Efter et møde mellem siddende præsident Robert Kocharyan, cheferne for de væbnede styrker, politiet og den Nationale Sikkerhedstjeneste indledte civilt politi, iført sorte lædermasker, sideløbende sporadiske arrestationer af oppositionelle i Jerevan under beskyldninger om ulovlig våbenbesiddelse, overgreb mod embedsmænd i funktion og planer om iværksættelse af et kup.

Situationen kulminerede foreløbigt tidligt om morgenen den 1 . marts, da fuldt udrustet uropoliti tiltvang sig adgang til Frihedspladsen med henvisning til at have modtaget oplysninger om våben og sprængstoffer blandt de demonstrerende.

Det kom til voldelige sammenstød mellem politi og demonstranter, og forsamlingen blev opløst. Ifølge officielle oplysninger blev 31 personer såret, og Levon Ter-Petrosyan førtes til sin bolig af politiet, skønt myndighederne konsekvent hævdede, at han ikke befandt sig under husarrest og frit kunne forlade sit hjem, hvis han ville fraskrive sig den politibeskyttelse han har nydt siden sin tid som præsident.

I formiddagens nyhedsudsendelser viste de officielle medier til gengæld uophørligt optagelser af de i alt tre håndskydevåben, et antal håndgranater, flasker med benzin til Molotovcocktails, tilspidsede træ- og metalstave samt kanyler og ampuller, fundet blandt de demonstrerendes ejendele. Hvorvidt disse genstande reelt befandt sig på stedet, hvilket ikke helt kan udelukkes, eller blev anbragt der af politiet med henblik på at retfærdiggøre dets indgriben, får vi dog sandsynligvis aldrig noget svar på.

Fordrevet fra Frihedspladsen spredte demonstranterne sig efterfølgende ud i de omliggende gader, men samledes i løbet af eftermiddagen på ny i den sydlige del af centrum på pladsen foran Frankrigs Ambassade og Jerevans nyopførte rådhus. Efter officielle angivelser var der omkring 7.000 personer. Heroverfor hævder andre, inkluderet venner af undertegnede, at der var tale om op mod 400.000 mennesker, men det tillader jeg mig dog at betvivle til fordel for et mere forsigtigt skøn på godt 30.000 .

\section{Voldsomme sammenstød}

Hvorom alting er, kom det imidlertid i de sene eftermiddagstimer og om aftenen til nye voldsomme sammenstød mellem ca. 1000 stenkastende demonstranter og uropoliti, de sidste bistået af militær i pansrede mandskabsvogne og bevæbnet med automatvåben.

Herunder blev i følge officielle angivelser otte personer dræbt (syv 
demonstranter og en politimand), et tal der dog sagtens kan være højere, hvis myndighederne har ladet de omkomne anbringe på flere forskellige mindre lighuse i byen, som stædige rygter i befolkningen vil vide.

Ifølge Sundhedsministeriet blev officielt 131 såret, heraf 72 politimænd og værnepligtige, men sundhedsministeren Harutioun Kushkiyan udtalte senere i et interview, at antallet af sårede, der havde modtaget hospitalshjælp efter urolighederne, var oppe på 230 personer. Desuden blev et større antal bybusser, politikøretøjer og privatbiler sat i brand og ødelagt, mens et nærliggende butikscenter blev vandaliseret og udplyndret.

Som svar på begivenhederne lod præsident Kocharyan omkring kl. 22.30 Jerevan erklære i undtagelsestilstand i 20 dage, og i de følgende timer tog kampvogne opstilling på byens større pladser og indfaldsveje, mens svært bevæbnede tropper bevogtede alle offentlige bygninger. I henhold til undtagelsestilstanden blev desuden alle massemøder, demonstrationer og strejker forbudt, såvel som sammenstimling af mere end tre personer, og der indførtes personkontrol af al privatbiltrafik ind og ud af byen.

Desuden indførtes forbud mod politisk propaganda uden myndighedernes tilladelse, og alle massemedier, inklusive internettet, blev mørkelagt med undtagelse af den statslige TV-kanal A+1, som dog kun måtte sende officielle informationer. Ikke desto mindre forekom demonstrationer den 2. marts i Armeniens næststørste by Gyumri, hvorunder mange blev arresteret, heriblandt en gammel ven af undertegnede, der dog blev løsladt sent om aftenen den 3. efter at være blevet tævet sønder og sammen på en lokal politistation.

Da jeg rejste fra Armenien den 7. marts hvilede en tung stemning over Jerevan, nærmest en choktilstand hos folk ved synet af kamptropper i gadebilledet og bevidstheden om, at armeniere for første gang i meget lang tid har dræbt andre armeniere i en politisk konflikt. Hertil kommer en såret selvfølelse hos mange, idet armenierne berettiget har været stolte over hidtil at have undgået de borgerkrigslignende tilstande, der for eksempel flere gange er forekommet i naborepublikken Georgien siden uafhængigheden, men nu føler at de har passeret en afgørende skillevej.

\section{Ny valglov}

Det store spørgsmål forbliver, hvorfor det kunne gå så galt?

Efter foreløbigt at have observeret otte armenske valg siden selvstændigheden, det ene ringere end det forrige, er der hos denne iagttager ingen tvivl om, at også dette seneste lå betragteligt under de standarder, som OSCE/ ODIHR lægger til 
grund for sine vurderinger, idet kandidat Serzh Sargsyan i modsat fald næppe ville være nået op over 50 procent af de afgivne stemmer.

Ganske vist har Armenien siden 2006 fået udarbejdet en ny valglov, der i betydelig grad har øget gennemskueligheden omkring diverse procedurer og derved reduceret mulighederne for fusk på selve valgdagen. Ligeledes har storstilede træningsprogrammer for medlemmer af valgkommissioner på både distrikts- og valgstedsniveau bidraget væsentligt til at forbedre disses professionalisme.

Begge disse aspekter gav sig således klart udtryk både ved parlamentsvalget i maj 2007 og nu igen under præsidentvalget 2008 , hvor kun et mindre antal af de udsendte korttidsobservatører fandt noget virkeligt graverende at rapportere om bagefter.

Fra et rent valgteknisk perspektiv må altså selve stemmeafgivelsen begge gange generelt siges at være gennemført i overensstemmelse med lovens bogstav. På den anden side har stort set samtlige langtidsobservatører (LTO'er) hver gang siddet tilbage med en fornemmelse af, at der var noget helt galt uden dog at kunne verificere deres mistanke, og som følge deraf haft meget svært ved at blåstemple OSCE/ODIHR's efterfølgende pressemeddelelser.

$\mathrm{Nu}$ forholder det sig sådan, at mens korttidsobservatørerne (STO'er) kun observerer selve valg- handlingen på et større eller mindre udsnit af et lands valgsteder, så følger man som langtidsobservatør den samlede valgproces i en given provins fra start til slutning, dvs. i helt op til to måneder, og er derfor ideelt langt bedre i stand til at danne sig et indtryk af lokale politiske forhold.

\section{Myndighedernes indblanding}

Fra en langtidsobservatørs synsvinkel er problemerne omkring de to seneste armenske valg altså helt klart koncentreret i perioden før valgdagen.

De drejer sig her især om myndighedernes forsøg på indblanding $\mathrm{i}$ valgprocessen gennem forskellige former for pression over for vælgerne til at stemme på en bestemt måde, underrepræsentation af oppositionelle eller blot ægte neutrale individer i valgkommissionerne, ulige betingelser for oppositionelle kandidaters og partiers valgkamp samt mangel på upartiskhed i de æterbårne massemedier, der dominerer nyhedsformidlingen.

Vanskeligheden her består i, at denne indblanding ofte er næsten umulig at verificere efter vestlig målestok. Hertil kræves konkret dokumention, modsat de løse rygter, påstande og konspirationsteorier, som typisk florerer i en politisk kultur, hvor magten og politikken altid hører til en bestemt klikes personlige gebet, og derfor for enhver pris 
søges gjort uigennemskuelig for en bredere offentlighed. Og hvor tilsvarende de fleste almindelige mennesker er yderst bevidste om risikoen ved at udtale sig om farlige emner og derfor skyr netop den form for konkret bevisførelse for deres påstande, som en langtidsobservatør efterlyser.

Stillet over for dette dilemma lades det i stedet op til den enkelte langtidsobservatørs lande- og kulturkendskab samt personlige integritet at vurdere, hvorvidt han eller hun tør satse sit omdømme på tilliden til de informanter, han møder i dagens løb, eller ej.

\section{Den 'Republikanske magtstruktur'}

Men for på denne baggrund at vende tilbage til nylige armenske præsidentvalg, kan man konstatere en ting med sikkerhed: nemlig at det statsbærende Republikanske Parti og hvad man kan kalde den 'Republikanske magtstruktur' på nuværende tidspunkt har udstrakt sin indflydelse til landets fjerneste afkroge på alle niveauer.

Partiet opstod oprindeligt på grundlag af de paramilitære grupper, der forsvarede Armeniens østgrænse i starten af krigen med Aserbajdsjan over Nagorno-Karabakh, men som blev afvæbnet af daværende præsident Levon Ter-Petrosyan i dennes forsøg på at opbygge en egentlig national hær i 1991.

Disse gruppers veteraner, samlet i den delvis hemmelige organisation 'Yerkrapah', var således allerede fra starten stærkt kritiske over for TerPetrosyan og sluttede derfor op bag det Republikanske Parti, der dengang især udmærkede sig ved en ekstremt armensk chauvinistisk retorik vendt imod præsidentens kompromissøgende politik over for Aserbajdsjan.

Som følge heraf henlevede partiet under dennes to præsidentperioder en ret obskur tilværelse, indtil det pludseligt manifesterede sig som støtteparti for den nyudnævnte premierminister Robert Kocharyan efter dennes sejr over Levon Ter-Petrosyan under det ekstraordinære præsidentvalg i Februar 1998.

Dets nyvundne magt understregedes yderligere under parlamentsvalget i 1999, hvor det fremstod som Armeniens dominerende politiske parti, en position det fastholdt under de efterfølgende parlamentsvalg i hhv. 2003 og 2007 i takt med, at det styrkede sit greb om statens institutioner.

På nuværende tidspunkt er det således svært at finde et landsbyoverhoved, en borgmester eller en provinsguvernør, der ikke enten er medlem af partiet eller udpeget direkte af præsidentembedet, hvis repræsentanter ligeledes dominerer diverse valgkommissioner.

Det betyder, at bare den formelle Republikanske magtstruktur i dag omfatter titusindvis af offentligt ansatte inden for stats- og lokal-admi- 
nistration såsom fx hele sundhedsog uddannelsessektoren, ordensmagten og forsvaret, for slet ikke at tale om det store erhvervsliv, som på forskellig måde har nydt godt af de herskende forhold.

Læg hertil den uformelle Republikanske magtstruktur i form af pårørende eller afhængige af disse eller med andre ord personer, der har en personlig interesse i at opretholde, hvad man kan kalde den republikanske fødekæde, for simpelthen at kunne overleve, og som derfor vil være tilbøjelige til at afgive deres stemmer til fordel for partiet. Dette er naturligvis helt legalt, idet vi trods alt taler om et land med en arbejdsløshed, der sine steder når op over 50 procent, og med en befolkning, som for 34,6 procents vedkommende lever under den officielle fattigdomsgrænse, hvorfor mange udelukkende klarer sig i kraft af deres personlige netværk og derfor står til at miste alt, hvis magtforholdene ændres.

\section{Underforstået pression}

Hvad der derimod ikke er legalt er, at der blandt alle disse individer utvivlsomt også findes mange, som ikke nødvendigvis støtter Republikanerne eller måske direkte er imod dem, men som ikke desto mindre er ekstremt sårbare over for pression fra magtstrukturens side. En sådan pression fra myndigheder eller private arbejdsgivere behøver ikke en gang at være direkte udtalt. Den ligger simpelthen i luften, idet alle kender betingelserne og derfor som regel foretrækker at føje sig.

Ikke desto mindre har jeg i årenes løb, også i forbindelse med det aktuelle valg, påhørt så mange beretninger om folk, der har mistet deres arbejde eller er blevet truet med at miste det, med mindre de stemte, som deres arbejdsgivere ønskede, at jeg personligt er fuldstændig overbevist om, at det er en vidt udbredt praksis.

På den anden side er det næsten umuligt at påvise konkret, da kun de færreste er beredte til at lægge navn til en formel anklage over for OSCE /ODIHR's langtidsobservatører, fordi de, som mange sandt nok erklærer, er tvungne til at blive tilbage $\mathrm{i}$ landet, når vi rejser.

Det kræver med andre ord et rigtig godt bryst at være en erklæret oppositionel i Armenien, og det er da også et skridt, som folk kun tager, hvis de er personligt uafhængige af den dominerende magtstruktur i kraft af egne indkomstkilder, eller hvis de alligevel ikke har noget at miste.

Men selv hvis vælgere ikke kan trues til at stemme for systemet, kan de ofte købes. Vedvarende rygter om køb og salg af stemmer for rede penge eller materielle goder til fordel for den Republikanske magtstruktur har været et tilbagevendende spørgsmål i forbindelse med de seneste armenske valg.

Personligt har jeg hørt om beløb 
på op til flere hundrede dollars for en stemme, hvilket på ingen måde er usandsynligt i betragtning af den nyrige elites formidable privatformuer og ønske om at fastholde deres magt over samfundets ressourser uanset prisen. Omvendt har jeg endnu ikke mødt en person, som åbenlyst har vedgået salg af sin stemme, ligesom jeg ikke helt kan gennemskue, hvad der forhindrer nogen i at tage imod pengene og så i øvrigt sætte sit kryds, hvor vedkommende lyster.

Et ledsagende problem omkring både vælgerintimidering og stemmekøb er imidlertid, at der generelt i Armenien eksisterer en udbredt mistillid til selve valghandlingens hemmeligholdelse, selv om det kan være vanskeligt for udenforstående at forstå. Det betyder, at mange fuldt og fast tror på, at myndighederne kan få oplyst, hvad den enkelte stemmer på, selv når vedkommende befinder sig alene bag forhænget $\mathrm{i}$ valglokalet.

Grunden hertil har givetvis til dels rod i Sovjetperioden, men skyldes også at i samfund som det armenske, især i landsbymiljøer, men selv i provinsbyer med op til 50.000 indbyggere kender alle hinanden og ved alt om hverandre som følge af den udbredte netværksmentalitet.

Pointen her er altså ikke, hvorvidt vælgerkontrol rent faktisk forekommer, men om vælgerne tror at det gør, og derfor mere eller mindre bevidst indretter sig derefter.

\section{Social elendighed}

Til trods for at det Republikanske Parti tilsyneladende besidder næsten uindskrænket kontrol over Armeniens politiske liv, enten direkte eller i kraft af taktiske alliancer med andre større partier, som fx Dashnaktsutioun, med hvem det har dannet regering siden parlamentsvalget sidste år, eller partiet Bargavach Hayastan (Velstående Armenien), stiftet af finansmogulen Gagik Sarukhyan i 2006, er der ingen tvivl om, at der eksisterer en udbredt folkelig utilfredshed med partiets regeringsførelse gennem de forløbne ni år.

Årsagerne hertil er først og fremmest af økonomisk natur, for selv om landet har kunnet fremvise en økonomisk vækstrate på 13 procent de senere år, og Jerevan oplever et veritabelt byggeboom, har udviklingen ikke smittet af på den brede befolknings levestandard. Det gælder især ude i provinserne, hvor arbejdsløsheden er astronomisk, og mange familier lever i yderste armod.

Sideløbende har monopoliseringen af den politiske magt siden selvstændigheden under først Levon Ter-Petrosyans Armenske Pan-Nationale Bevægelse - Hayastan Hamasgayin Sharzhum (HHsh) - og derefter Robert Kocharyan og det Republikanske Parti medført, at staten ikke har formået at opbygge den fornødne legitimitet $\mathrm{i}$ befolkningen til $\mathrm{fx}$ at få denne til at bidrage frivilligt til dens ressourcer gennem skatteind- 
betaling, hvorfor den offentlige ældreforsorg, sundhedsvæsenet og undervisningssystemet er i en sørgelig forfatning.

Som svar på de elendige levevilkår og manglen på fremtidsudsigter har måske helt op mod en million armeniere derfor gennem de seneste 15 år valgt at forlade landet enten permanent eller som sæsonarbejdere især i Rusland. Disse emigranter tegner sig til gengæld for en betragtelig del af de tilbageblevnes daglige økonomi i form af pengeoverførsler til deres familier hjemme.

Det er derfor ikke overraskende, at mange ældre og midaldrende tænker tilbage til Sovjetperioden med nostalgi, al den stund Armenien dengang nød ry som en af de mest velstående af de nationale republikker i kraft af en betydelig industrivirksomhed og en af de højst uddannede befolkninger i føderationen.

Den dårlige levestandard blandt almindelige mennesker står i grel kontrast til den herskende elite af nyriges, måske fem procent af befolkningens, prangende livsstil og overdådige luksusforbrug, opnået gennem godt tilsløret spekulation i regeringens privatiserings-programmer, herunder salg af nationale industri- og råstofressourcer til udenlandske selskaber, især russiske. Således menes Rusland for nærværende at kontrollere omkring 80 procent af Armeniens energikilder, inklusive atomkraft-anlægget Metsamor uden for Jerevan og en gasrørledning fra Iran, der er under opførelse.

Denne politik har muliggjort Ruslands fortsatte militære tilstedeværelse i landet i form af basefaciliteter og et tæt forsvarssamarbejde, der fastholder Armenien som Moskvas sidste strategiske allierede i Sydkaukasus, et forhold der af mange armeniere ses som en hindring for åbning mod resten af verden.

\section{Magtmisbrug}

Til den $\varnothing$ konomiske elendighed lægger sig dyb modvilje over for den Republikanske magtstrukturs politiske magtmisbrug, ikke blot i valgsammenhæng, men også til daglig, og dermed den tiltagende retsløshed, der har præget samfundet siden partiets regeringsovertagelse.

Her tænkes især på det, der har fået navnet Oktober 1999-begivenheden, hvor den dengang nyligt udnæunte premierminister Vazgen Sargsyan, parlamentsformanden Karen Demirchiyan og 6 andre højtstående embedsmænd og parlamentsmedlemmer blev dræbt af en attentatmand, der trængte sig ind i parlamentsbygningen under et møde. Han blev senere pågrebet og officielt idømt livsvarigt fængsel for mordene, men retssagen blev hemmeligholdt, og det er derfor en udbredt opfattelse i offentligheden, at om ikke præsident Kocharyan så $\mathrm{i}$ hvert fald den republikanske inderkreds stod bag. 
Hertil kommer i marts 2007 en senere premierminister, nemlig Andranik Markaryans, yderst belejligede død af et hjerteslag, der banede vej for daværende forsvarsminister Serzh Sargsyans overtagelse af hans post, og dermed førerpladsen som den Republikanske magtstrukturs kandidat til præsidentvalget i år. Endelig blev både borgmesteren og viceborgmesteren i Gyumri kun få uger senere beskudt og hårdt sårede på vej hjem fra en republikansk partikonference i Jerevan, og selv om dette sandsynligvis havde årsag i et internt opgør mellem kriminelle grupper, idet samme borgmester har et meget blakket ry i Gyumri, er attentatmændene aldrig blevet pågrebet, og ikke mange tror på at dette er tilfældigt.

I hvert fald har begivenheder som de nævnte bidraget til at skabe, hvad mange informanter har beskrevet over for undertegnede som 'en udbredt stemning af frygt' i offentligheden, men tillige skærpet utilfredsheden.

\section{'Karabakh-klanen'}

Vreden mod den regerende elite under præsident Kocharyan har desuden gennem de senere år fået en overraskende dimension, idet både denne og en række af Armeniens øvige topfolk oprindeligt stammer fra Nagorno-Karabakh, den armensk befolkede enklave i Aserbajdsjan over hvilken de to stater ud- kæmpede en bitter konflikt i 198894, og derfor ofte omtales som den såkaldte Karabakh-klan.

Allerede Levon Ter-Petrosyan bragte under sin tid som præsident flere embedsmænd fra enklaven ind i sin regering, herunder den nyvalgte præsident Serzh Sargsyan, der tjente som forsvarsminister fra 1993, samt i 1997 også Robert Kocharyan selv, altså med andre ord netop de to personer, som i 1998 spillede nøglerollen i den parlamentsmanøvre, der tvang ham til at træede tilbage.

Tendensen er fortsat under Præsident Kocharyan, og der menes i dag at være omkring 15.000 tilflyttere fra Nagorno-Karabakh, som har slået sig ned i Armenien. Heriblandt er der 20-30 familier, som takket være deres særlige forbindelser til statens øverste myndigheder, er blevet ufatteligt rige i kraft af muligheder for at unddrage sig skatte- og toldafgifter samt sikre sig monopol på brændstoffer, sukker og andre varer.

Blandt disse omtales fx Kocharyans søn Sedrak Kocharyan, som hævdes at kontrollere importen af mobiltelefoner; Barsegh Beglaryan, som dominerer markedet for tankstationer; Mika Baghdasaryan, som står i spidsen for olieimporten og det nationale luftfartsselskab, og endelig Karen Karapetyan, som leder Armruzgazard, et joint venture gasselskab med Ruslands Gazprom.

'Karabakhtsierne' hæudes endvidere at stå i vejen for en endelig løs- 
ning på Karabakh-konflikten, eftersom de nyder godt af den lukkede grænser mod Aserbajdsjan og Tyrkiet, som gør det lettere at kontrollere bevægelserne af varer via Georgien og Iran.

Denne politik hindrer samtidig udviklingen af den hjemlige småindustri og handel til fordel for det store forretningsliv, men lammer ultimativt landets økonomi. Det er da heller ikke overraskende, at en del af støtten til fx Levon Ter-Petrosyan netop kommer fra små og selv mellemstore erhvervsdrivende.

Reelt eksisterer der ikke de store kulturforskelle mellem armeniere fra Republikken Armenien, de såkaldte 'Hayastantsi', og 'Karabakhtsierne', selv om de sidste tenderer til at være mere positivt indstillede over for Rusland, ofte taler bedre russisk og er mindre religiøse end de første. På den anden side er der ingen tvivl om, at favoriseringen af især Kocharyans og Sargsyans allierede samt den omstændighed, at Karabakh i dag fremstår som den infrastrukturelt og økonomisk mest velstillede del af det samlede armensk beboede territorium, har bidraget til at øge modviljen over for den Republikanske magtstruktur i almindelighed.

Selv for denne iagttager, som oplevede Karabakh-bevægelsens storhedstid fra slutningen af 1980'erne, med dens massemøder og følelsesladede slagord om det moderløse Karabakhs tilbagevenden til Armenien, er det ikke uden en vis ironi at kunne konstatere, at det i dag er det samme Karabakh, som tilsyneladende har overtaget republikken.

\section{Fra magtesløshed til modstand}

Hvorom alting er, eksisterer der af alle de ovennæunte årsager en altomfattende følelse af frustration i brede udsnit af den armenske befolkning, først og fremmest dens fattigste lag, men også blandt mindre næringsdrivende og resterne af den veluddannede middelklasse af videnskabsmænd og andre intellektuelle fra Sovjetperioden, som er blevet hårdt ramt af den røverkapitalisme, som er opstået efter selvstændigheden.

Frustrationen er så meget større, fordi der efter det seneste præsidentvalg ikke længere er udsigt til nogen umiddelbar ændring af tingenes tilstand. Det er lige præcis denne frustration, som Levon Ter-Petrosyan har formået at gøre sig til talsmand og samlingspunkt for med sine flamboyante udtalelser og andre initiativer i kølvandet på valget.

På den anden side er dog værd at huske på, at han selv langt fra er nogen idealistisk oppositionel, men tværtimod har et særdeles blakket ry fra sin tid som præsident og sandsynligvis ville optræde ganske som den Republikanske magtstruktur, blot med andre aktører.

For eksempel var det Levon TerPetrosyan, der først bragte kampvog- 


\section{SØREN THEISEN}

ne ind i Jerevans gader, da Vazgen Manoukyan, hans hovedrival ved præsidentvalget i 1996, udfordrede valgresultatet, ligesom mange andre af de problemer, der præger Armenien i dag, reelt blev grundlagt med ham og hans tilhængere i spidsen for statens ledelse.

Det husker mange armeniere ganske udmærket, og når de demonstrerende den 1. marts derfor brugte hans navn som slagord, er det ikke nødvendigvis fordi de ønsker ham tilbage som statsleder, men nok så meget fordi han på nuværende tidspunkt fremstår som det mest synlige alternativ, og fordi de ville markere deres vrede over den Republikanske magtstrukturs videreførelse af sin dominans efter nok et uigen- nemskueligt valgresultat. Den situation der foreligger i Armenien nu, er således uden tvivl et resultat af Republikanernes misregimente gennem de sidste ni år; men de begivenheder som udløste undtagelsestilstanden, blev ligeså sikkert fremprovokeret af Levon Ter-Petrosyan og hans tidligere netværk i deres egen interesse.

$\mathrm{Og}$ - som så ofte før er det igen almindelige mennesker i det hårdtprøvede land, der må bære konsekvenserne.

Søren Theisen er historiker. Han har varet observatør for OECD ved de fleste valg $i$ Sydkaukasus siden uafhangigheden. 